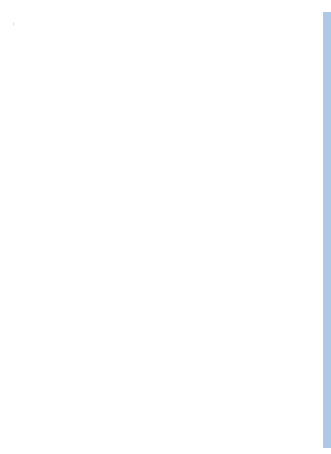

Journal of Geology. Geography and

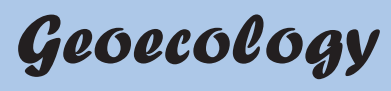

Journal home page: geology-dnu.dp.ua
ISSN 2617-2909 (print)

ISSN 2617-2119 (online)

Journ. Geol. Geograph. Geology, 30(4), 754-761. doi: $10.15421 / 112169$

\title{
A new species of palaeosiphonocladal algae Kamaena gigantea from the Lower-lowermost Middle Mississippian sediments of the Donbas (Upper Tournaisian-Lower Visean)
}

\author{
Oleh A. Sukhov
}

Institute of Geological Sciences, NAS of Ukraine, 55-b O. Honchara St., Kyiv, Ukraine, 01601 osukhow74@ukr.net osukhow7480@gmail.com

\section{Received: 09.08.2020 \\ Received in revised form: 05.09.2021 \\ Accepted: 01.10.2021}

\begin{abstract}
A new species of green paleosiphonocladal algae Kamaena gigantea from the Lower-lowermost Middle Mississippian sediments of the Donbas has been described. This species was distinguished from other representatives of the genus Kamaena Antropov by its extremely large size, tortuous shape of the thallus and convex partitions. The species
\end{abstract} belongs to an artificial taxonomic unit of the Kamaenae Shuysky tribe, 1985, of the family Palaeoberesellaceae Mamet et Roux , a systematic grouping which is still controversial. The attribution of this family to green siphonocladal algae is controversial and quite conditional, the opinions of different authors being based on personal vision, and varying in range from the plant to the animal kingdom. A characteristic feature of the family is the tubular shape, the segments of which are connected by partitions with a large central pore, sometimes with additional small pores. The thallus wall (fossilized remains of the body) is porous or non-porous and has simple or branched pores. It has been emphasized that study of Paleoberezellides in thin sections, the sometimes fuzzy images of the typical material in publications and ignorance of other researchers' publications have caused confusion and led to the selection of an unreasonably large number of genera and species within the family. It has been noted that in previous works, representatives of this species were mistakenly identified as Anthracoporellopsis Maslov, a genus characteristic of the Lower-Middle Pennsylvanian sediments. This erroneous definition was based mainly on general external similarity, a poorly illustrated description of the type species, and did not take into account the morphological features that were characteristic for the genus. It has been found that representatives of the new species had a rather limited stratigraphic distribution: the Upper Tournaisian (Dokuchaevskian horizon) and the Lower Visean (Hlybokian-Sukhinskian horizons), and the most similar specimens found in the Ural region in underlying Tournaisian sediments were, unfortunately, poorly illustrated and smaller in size and had a narrower thallus. It has been noted that a characteristic feature of the tribe Kamaenae Shuysky, 1985 was the tubular shape, its inter-segmental partitions were perpendicular to the walls and were at the approximately same interval from each other. It has been pointed out that representatives of the new species were found mainly in grainstones, packstones, and wackstones - organogenic-detrital limestones along with such groups of microfauna as echinoderms and ostracods, isolated spicules of sponges and remains of worms. The material for illustrations was mainly taken from the borehole 74 (near the village of Rodnikove, Starobeshiv district, Donetsk region), which most fully revealed the Lower-Middle Pennsylvanian deposits of the southern part of the Donbas. The knowledge of the systematic composition of the Early Carboniferous algoflora has been expanded. This has helped us to conclude that the tribe Kamaeneae Shuysky, 1985 ,includes 6 genera and at least 22 species that were found in the layers from the Early Devonian to the Early Visean of the Lower Carboniferous.

Keywords: Lower-lowermost Middle Mississippian, Upper Tournaisian-Lower Visean, Donbas, green algae, new species.

\section{Новий вид палеосифонокладової водорості Kamaena gigantea з верхньотурнейських- нижньовізейськихв відкладів нижнього-самих низів середнього міссісіпію Донбасу}

\section{O.A. Сухов}

Інститут геологічних наук НАН Украӥни, вул. О. Гончара, Київ, Украӥна, 01601 osukhov74@ukr.net osukhow7480@gmail.com.

Анотація. 3 верхньотурнейських-нижньовізейських відкладів нижнього-самих низів середнього пенсильванію Донбасу описано новий вид зеленої палеосифонокладової водорості Kamaena gigantea. Від інших представників роду Kaтаеna Antropov, 1967 даний вид відрізняється надзвичайно крупними розмірами, звивистою формою талліта та випуклими перегородками. Проведено історичний екскурс та розглянуто загальні питання систематичної належності родини Palaeoberesellaceae Mamet et Roux. Зазначено, що систематична належність цієї родини $є$ дискусійною і досить умовною, а думки різних авторів дуже різняться в залежності від особистого бачення і варіюють від рослинного до тваринного царства. Наголошено, що вивчення палеоберезелід в тонких шліфах, іноді погані зображення типового матеріалу в публікаціях та незнання самих публікацій інших дослідників стало причиною плутанини та призвело до виділення невиправдано великої 
кількості родів та видів всередині родини. Встановлено, що представника нового виду мають досить обмежене стратиграфічне поширення: пізній турне (докучаєвський горизонт) та ранній візе (глибокинський-сухинський горизонти), а найбільш подібні екземпляри зустрінуті в Уральському регіоні у нижчезалягаючих відкладах турне, проте вони погано проілюстровані, мають відчутно менші розміри та вужчий таліт. Початкове помилкове визначення виду базується головним чином на загальній зовнішній схожості, погано проілюстрованому опису типового виду та не бере до уваги морфологічних ознак, які характерні для роду Anthracoporellopsis Maslov, 1956 з відкладів середнього та пізнього карбону. Вказано на те, що представники нового виду виявлені переважно у грейнстоунах, пакстоунах, вакстоунах. Розширено пізнання про систематичний склад ранньокам'яновугільної альгофлори. Вказано, що на сьогодні до тріби Kamaeneae Shuysky, 1985 входять 6 родів і щонайменше 22 види, представники яких зустрічаються від верхнього девону до верхнього візе середнього міссісіпію.

Ключові слова: міссісіпій, верхній турне-нижній візе, Донбас, зелені водорості, новий вид.

\section{Introduction.}

The family Palaeoberesellaceae Mamet et Roux are microorganisms that have the form of perforated calcareous tubes segmented inside the partitions in thin sections. These organisms were an important biotic component of the shallow areas of the Late Devonian and the Early Carboniferous seas, and sometimes they had rock-forming importance along with other organisms.

The history of study of Paleoberezellides dates back to the 19-th century when they were identified as foraminifera Nodosinella (Brady, 1876). In the process of further study, the group was attributed to both plant and animal kingdoms (Maslov, 1956; Antropov, 1968; Termier, Vachard, 1977; Bassoulet, 1979; Berger, Kaever, 1992).

Paleoberezellides were first revised by B. Mamet and A. Roux (Mamet et Roux, 1974). Based on the existing genera - Kamaena Antropov 1967 Pseudokamaena Mamet (in Petryk et Mamet 1972), Exvotarisella Elliot 1970,? Anthracoporellopsis Maslov 1956 and three new genera Kamaenella, Palaeoberesella and Parakamaena, they classified this tribe as Palaeobereselleae. The tribe, with some doubt, was included in the Dasycladales order. According to these authors, the taxonomy of the proposed Palaeobereselleae tribe was based mainly on the general appearance of "cells" and transverse partitions, the type of wall porosity and their size (Fig. 1).

Based on the method of studying Paleoberezellides in thin sections, sometimes poor images of typical material and ignorance of the publications of other researchers caused confusion and led to the establishment of an unreasonably large number of genera and species within the family. Among such examples was the genus Exvotarisella Elliot originally described as the foraminifera Nodosinella index (Brady, 1876). G. Elliott (Elliott, 1970) described a new species of Exvotarisella maponi from the Visean sediments of England, referring it to the family Dasycladaceae (Kützing, 1843). The species was well illustrated and among its characteristic features was branching of the pores of the first and second order. B. Mamet and A. Roux (Mamet, Roux, 1974) re-described the genus, making the species $E$. index the type species and introducing the species E. maponi into the synonym. Moreover, among numerous images only the Figure 24 from the Table 5 has porosity of the wall and branching of the first order.

Currently, the family includes 15 genera and about 42 species (Chuvashov, Luchinina, Shuisky, 1987), some of which are obviously synonymous.

The issue was well covered by P. Brenckle (Brenckle, 1985) who supported combining Paleoberezelides and their descendants Berezellides into a new family or group of higher taxonomic rank inside the green algae as long as their true taxonomic status remained to be discovered.

\section{Research materials and methods.}

The material of the study was several dozen specimens of Paleoberezellides previously identified as Anthracoporellopsis Maslov and mostly satisfactorily preserved. They were found in thin sections of boreholes and outcrops in the Donbas. Samples for the study were taken from the following locations: boreholes 9, 74, quarry near Dokuchaevsk - Central; Stylsk quarry in Volnovakha and Starobeshiv districts in Donetsk region. Based on this material, the biological diversity of the family Palaeoberesellaceae Mamet et Roux in the Visean sediments of the Donbas has been studied for the first time, and their vertical distribution and taxonomic diversity have been analyzed.

Considering the degree of preservation of the material, only specimens from the borehole 74 have been presented in this paper (Fig. 2).

The main research methods were micropaleontological and biostratigraphical. The calcareous algae have been studied in thin sections under the MBI-3 microscope.

\section{Results and their analysis}

As a result of the study of the Late TournaisianEarly Visean algae in the southern part of the Donbas, calcified remains of tubular algae previously mistakenly identified as Anthracoporellopsis machaevi Maslov were found. This initial judgment was based on their large size, massive oblique walls and uneven partitions separating the inner cavity. The stratigraphic distribution of these forms includes the deposits of Dokuchaevskian horizon of the Lower Tournaisian to Sukhinskian hori- 


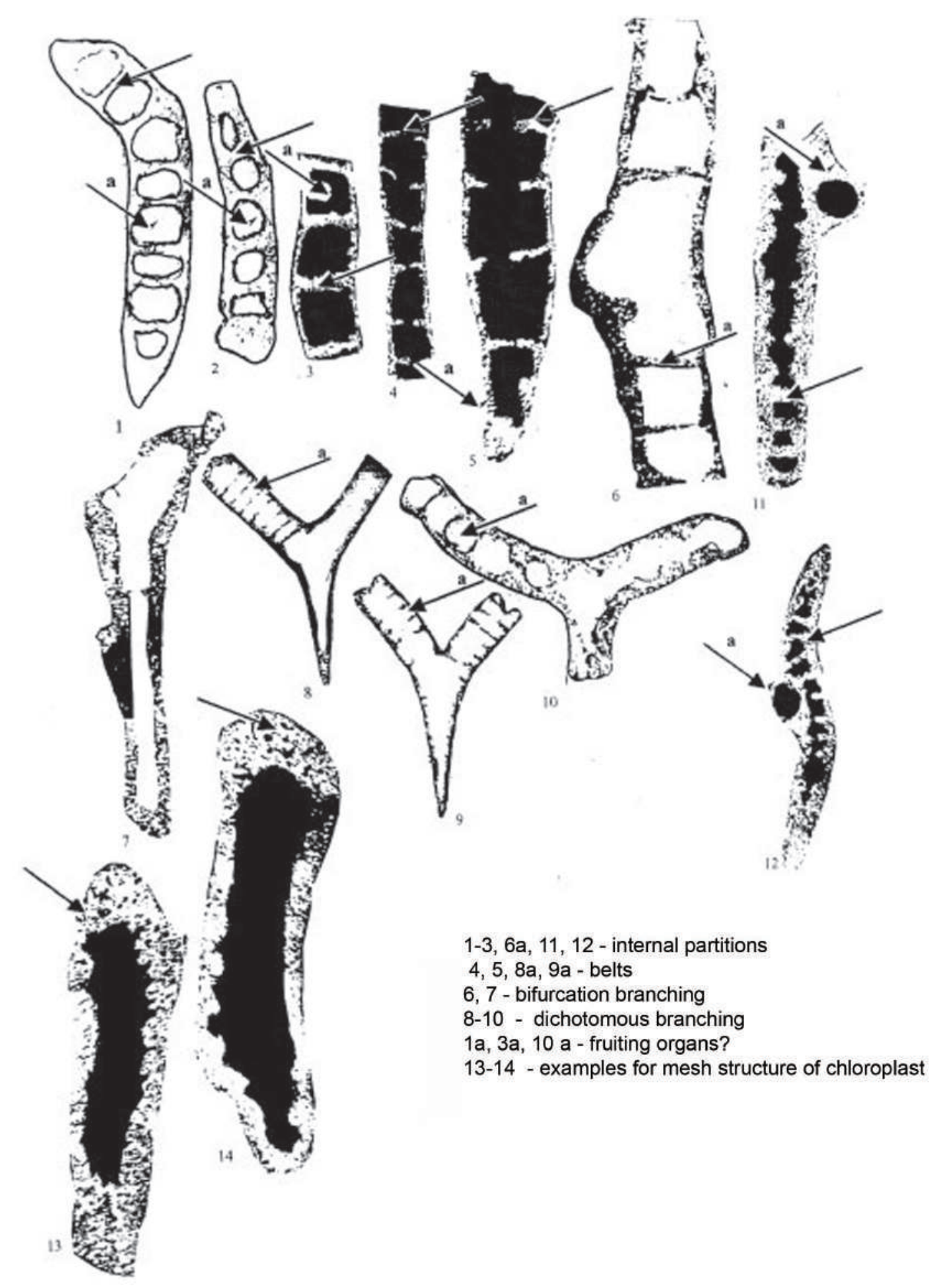

Fig. 1. Some examples of morphological elements (features) of the family Palaeoberesellaceae Mamet et Roux 


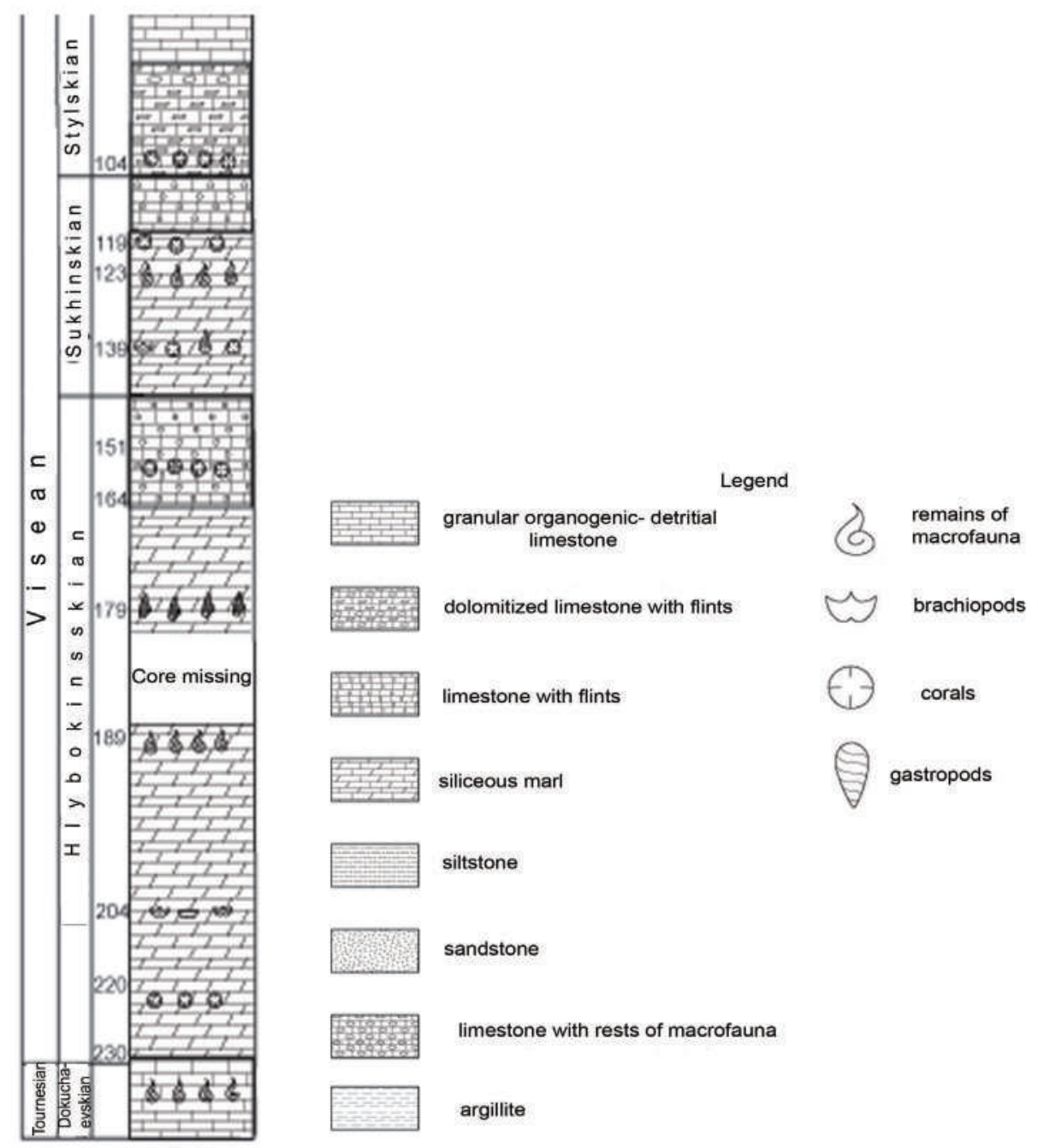

Fig. 2. Lithological section of borehole 74

zon of the Middle Mississippian. However, studying of the algae of the family Palaeoberesellaceae Mamet et Roux showed that such judgements were wrong according to the latest ideas about the taxonomic belonging of the family and its individual genera. In addition, a discrepancy was revealed between our and other specimens and the underlying sediments with typical specimens.

The genus Anthracoporellopsis described by Maslov (Maslov, 1956) apparently taken from Bashkirian deposits of the Donbas is characterized as a tubular organism with partitions and channels, with a double dichotomous branching of pores in the walls. Typical material had channels in the partitions which were of curved shape, often with protuberances going into the internal cavity of the body (Fig. 3). Their important additional characteristic was walls made of light calcite and pores-channels filled with dark carbonate. The author also described a thin, light carbonate crust on the outside of the walls that brought the genus closer to the Beresellaceae family Maslov et Kulik, 1956, and indicated the likelihood of their close phylogenetic links. However, the description of the typical species was poorly illustrated by photographs, and has more hypothetical sketches that later led to confusion and erroneous definitions.

Our material is a large tubular alga with partitions. The wall is composed mainly of light calcite and has no additional layer. Pseudopores are thin and composed of light carbonate with dichotomous branching on some specimens. Such features gave grounds to redescribe the existing specimens and refer them to the genus Kamaena Antropov, which is very similar to them. The stratigraphic distribution of the taxon in the Donbas is quite limited: the Upper Tournaisian (Dokuchaevskian horizon) - the Lower Visean (Hlybokinskian and Sukhinskian horizons). Moreover, the most widespread representatives of the taxon are in the deposits of Hlybokinskian horizon. The specimens of this taxon are found mainly in packstones, wackstones, rarely grainstones - organogenic limestones with predominance of foraminifera, tubular green algae with 

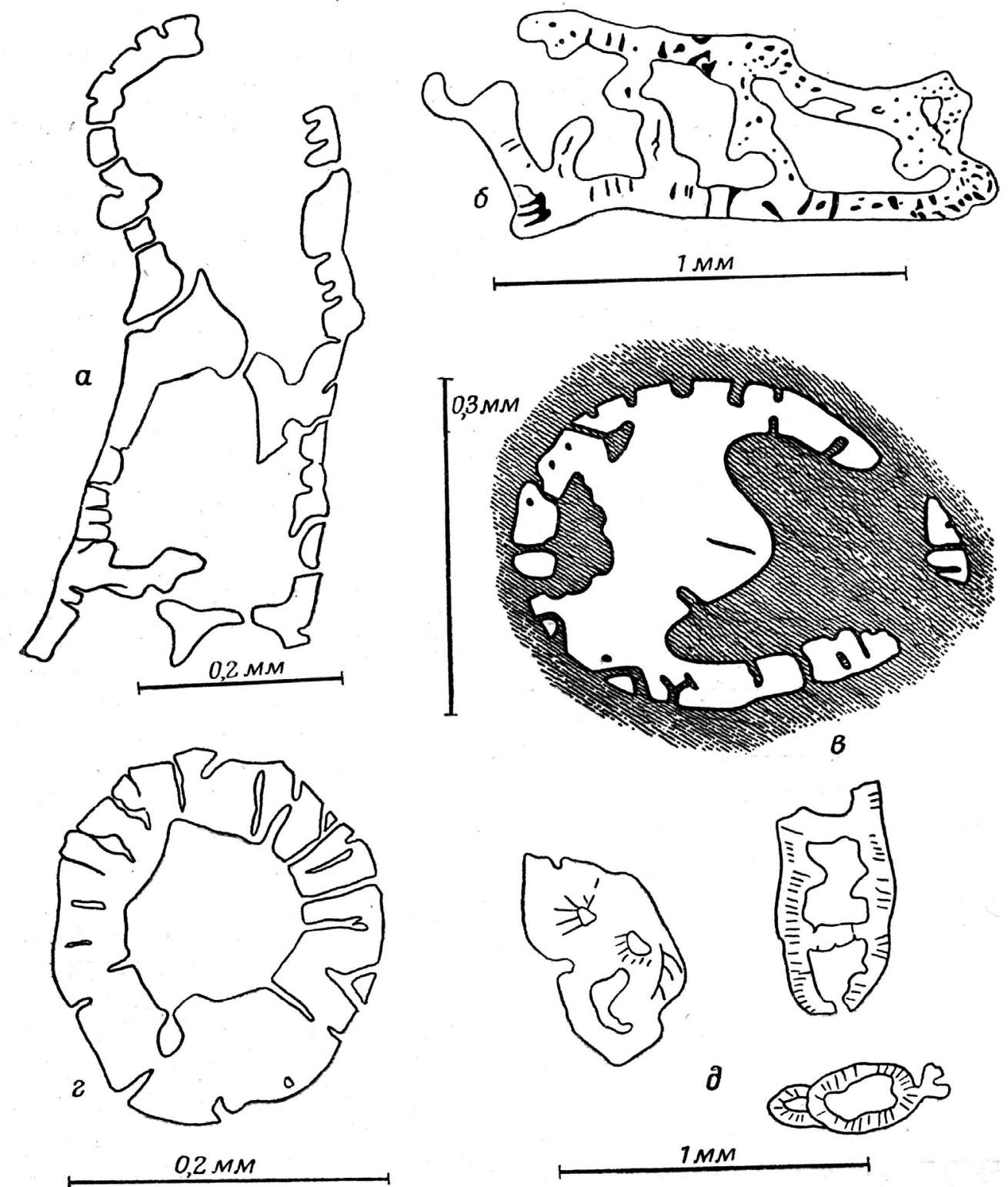

Fig. 3 Schematic representation of the genus Anthracoporellopsis (Maslov, 1956)

septa, occasionally there are remains of echinoderms and ostracods and isolated spicules of sponges and remains of worms.

\section{Family PALAEOBERESELLACEAE Mamet et} Roux, 1974

Intersegmental partitions with large central pore, sometimes with additional small pores; thallus wall is porous or non-porous, its pores are simple or branched.

Tribe KAMAENAE Shuysky, 1985

Intersegmental partitions are perpendicular to the wall and are at approximately the same distance from each other. The pores in the wall are straight, unbranched.

Representatives of the Kamaenae Shuysky tribe are widely represented in the limestone strata of the Visean deposits of the Donbas. The systematic position of this tribe, as well as the whole family Palaeoberesellaceae, still remains uncertain. This group includes calcareous tubular microorganisms having an internal cavity divided by transverse partitions into chambers. Today, the tribe Kamaeneae Antropov includes 6 genera and at least 22 species, representatives of which are found from the Lower Devonian to the Upper Visean (Serpukhov?) of the Mississippian- Lower Pennsylvanian?

\section{Genus Kamaena Antropov, 1967}

Type species: Kamaena delicata Antropov, 1967; Tournaisian, the Zavolgian horizon of the Tatar AR. Diagnosis. Thallus is cylindrical, tortuous, in the cross section it is rounded, dichotomously and alternately branched. Its inner partitions in the longitudinal section are straight and placed perpendicular to the wall. 


\section{Species composition and distribution.}

The genus has 10 species:

Kamaena delicata Antropov was found in upper part of Famennian stage of the Devonian and the Mississippian of the Eastern European Platform, of the Tournaisian and Visean stages of the Donbas, Western Europe, Poland, North America;

$K$. awirsi Mamet et Roux was found in the Tournaisian and Visean stages of the Donbas, Urals, Siberia and Northeastern Russia, the Visean stage of the Eastern slope of the Urals, Western Europe, Poland;

$K$. itkillikensis Mamet et Rudloff was found in the Upper Famennian of Russia, the Tournaisian and Visean deposits of Western Europe, Donbas, North America, Visean of the Urals;

$K$. maclareni Memet et Rudloff was found in the Tournaisian deposits of the North America (Keokuk Formation);

K. minuta R. Ivanova was found in the Upper Famennian-Lower Tournaisian of North-Eastern Russia;

$K$. lata R. Ivanova was found in the Lower Touraisian of the Urals and the Kolyma Massif of North-Eastern Russia, in the Upper Famennian-Lower Tournaisian of the Momsky Ridge and the Omolon Massif, Upper Tournaisian of the Siberian Platform, the Lower Visean of Ukraine;

$K$. omolonica R. Ivanova was found in the Visean stage of the Omolon Massif(Russia), the Lower Visean of Donbas (Ukraine);

K. magna R. Ivanova was found in the Visean sediments of the Kolyma Massif, the Urals, the Eastern European Platform (Russia), Ireland, Morocco; the Tournaisian of Ukraine and the Ural-Kazakh depression (Russia); the Famennian and Tournaisian of France;

$K$. tobolensis R. Ivanova was found in the Lower Tournaisian of the Ural-Kazakh depression (Russia);

$K$. maclareni Mamet et Rudloff was found in the Tournaisian sediments of North America.

Kamaena gigantea sp. nov.

Plate 1, Fig. 1-8; Plate 2, Fig.1-4

Derivatio nominis. From gigantea (lat.) - huge.

Holotype: IGS NAS of Ukraine, brh. 74, area near village Rodnikove, Starobeshiv districts in Donetsk region, dth. 231-233.7 M, sample. 98, Dokuchaevskian horizon, zone $\mathrm{C}_{1} \mathrm{v}$.

Anthacoporellopsis machaevi Maslov: OI Berchenko, 1981, Table. 28 Figure 1 Anthacoporellopsis machaevi Maslov: O.I. Berchenko, O.A. Sukhov, table. 13, Fig. 1 1-3, 5-7, 11

Name derivation: from the gigantea (lat.) - huge.

Description. The thallus is large, tubular, curved, its shape varies from subcylindrical, subconical and subrectangular depending on the cross section. Its wall is quite thick, uneven, "porous", sometimes with protuberances, mostly on the outside, and has irregular "pores". "Pores" are mostly straight, not branched and not all specimens have them. Pores are located perpendicular to the wall. Partitions are infrequent, straight or curved to the central part of the thallus. They are placed at approximately the same distance from each other and perpendicularly or at an angle to the wall and have approximately the same thickness. Their inner cavity is wide.

Dimensions in microns. The thallus diameter is 270-630, wall thickness is 30 - 70, thickness of partitions is $25-70$, distance between partitions is $110-420$, diameter of the "pores" is 3-10, diameter of the inner cavity is $100-600$.

Comparison. Our specimens are most similar to the species Kamaena lata R. Ivanova and Kamaena magna R. Ivanova from the Tournaisian sediments of the Urals, but they differ from Tournaisian ones by greater width of the inner cavity and much greater distance between partitions and larger size of all elements of the thallus. In addition, unfortunately, R. Ivanova's material is poorly illustrated: K. lata has two specimens, $K$. magna has three specimens that make it impossible to clearly identify them.

Distribution. The Late Tournaisian-Early Visean stage of Donbas (Ukraine).

Location and material. Donbas, DokuchaevskianSukhinskian horizons, area near village Rodnikove, 74, dth. 231-233 m, 216.6-218.0 m, 206.8-209.0 m, 203.9-205.6 m, $188.5 \mathrm{~m}, 144.4-148.2 \mathrm{~m}, 142.4-144.4$ m, 139.2-142.4 m, $138.0 \mathrm{~m}, 133.5 \mathrm{~m}, 124 \mathrm{~m}, 55.8-$ $58.2 \mathrm{~m}$, Dokuchaevskian - Hlybokianskian horizons (zones $\mathrm{C}_{1}{ }_{1 \mathrm{a}}, \mathrm{C}_{1 \mathrm{~b}-\mathrm{c}}, \mathrm{C}_{1 \mathrm{~d}}{ }_{\mathrm{d}}$ ); near village of Styla, borehole. 30 , dth. $229.3 \mathrm{~m}, 228.8 \mathrm{~m}, 226.0 \mathrm{~m}, 224.8 \mathrm{~m}$, Dokuchaevskian horizon (zone $\mathrm{C}_{1}{ }_{\mathrm{a}}$ ), the area of the town of Novotroitske, borehole 9, dth. 294.5 m, 292.5 m, $291.6 \mathrm{~m}$, Dokuchaevskian horizon (zone $\mathrm{C}_{1 \mathrm{a}}^{\mathrm{v}}$ ), the area of the town of Dokuchaevsk, quarry Central zone, Dokuchaevskian-Hlybokianskian horizons (zones $\mathrm{C}_{1 \text { b-c }}^{\mathrm{v}}$, $\mathrm{C}_{1 \mathrm{~d}}^{\mathrm{v}}$ ). More than 40 specimens in longitudinal and cross sections.

\section{Conclusion.}

This article presents a revision of the systematic position and a description of a new species of Palaeosiphonocladal algae Kamaena gigantea from the Lower Carboniferous deposits of the Donbas . We established that its stratigraphic distribution is limited to the deposits of the Dokuchaevskian or Late Tournaisian and Sukhinskian horizons of the Early Visean. We analysed previous publications from the history of study and gave an explanation why the new species was identified. We made a comparison of similar species in other territories and carried out a revision. We widened the knowledge on the palaeoalgal flora of the Donetsk Seas of the Carboniferous and established the facies position of the new species. 


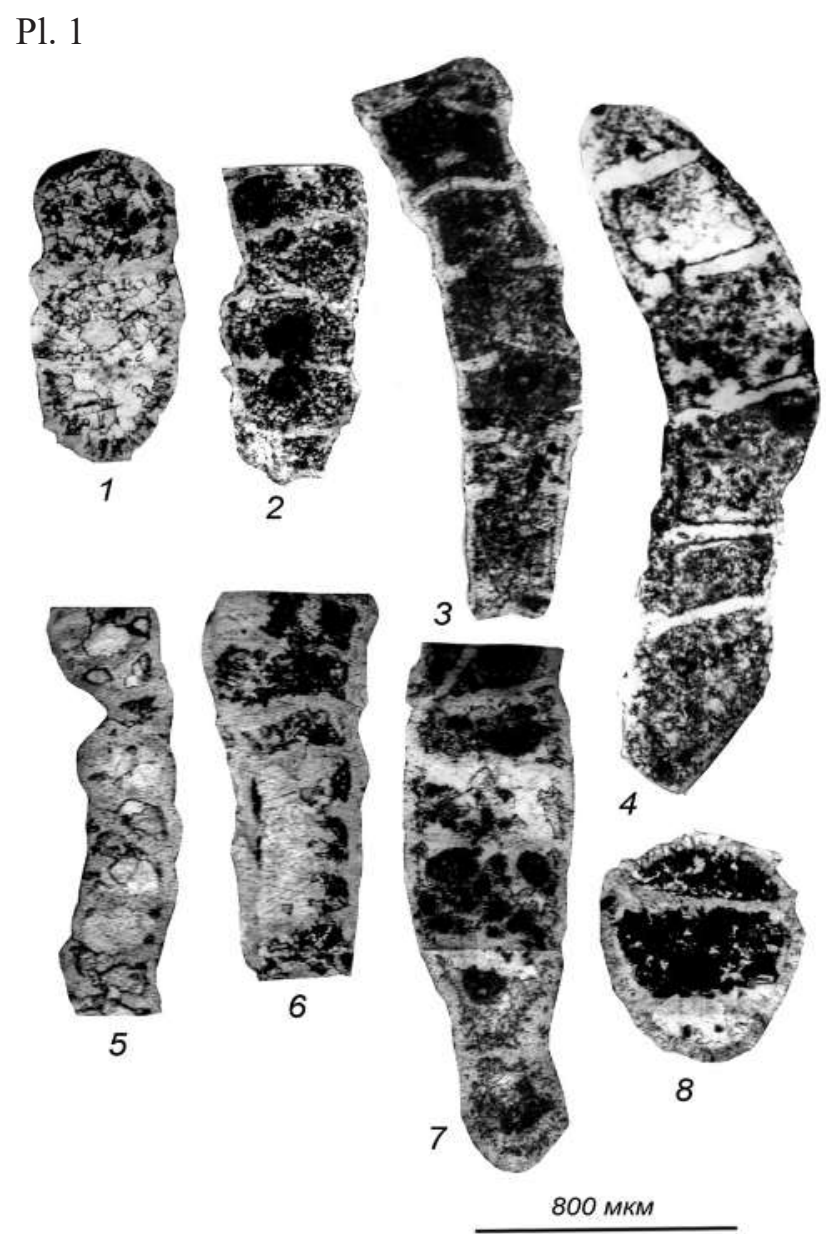

P1. 1 $\mathrm{C}_{1 \mathrm{c},}^{\mathrm{v}}$,

Fig. 7, 8 depth 144.4 m, Hlybokinsky horizon, zone

Fig. 1, 4 depth 203.9-205.6 m, Hlybokinsky horizon, zone $\mathrm{C}_{1 \mathrm{~b}-\mathrm{c}}^{\mathrm{v}}$,

Fig.3 depth 231-233.7 m, Dokuchaevskian horizon, zone $\mathrm{C}_{1}{ }^{\mathrm{a}}$ a

Fig. 2 depth $138 \mathrm{~m}$, Hlybokinsky horizon, zone $\mathrm{C}_{1 \mathrm{~d}}^{\mathrm{v}}$,

Fig. 6 depth 139.2 -142.4 m, Hlybokinsky horizon, zone $\mathrm{C}_{1}^{\mathrm{v}}$,

Fig 5 depth $188.5 \mathrm{~m}$, zone $\mathrm{C}_{1 \mathrm{~d}}^{\mathrm{v}}$.

\section{References}

Antropov, I.A., 1968. Vodorosli devona i nizhnego carbona /turne/ Tsentralnoi chasti vostoka Russkoi platformy. Isskopajemyje vodorosli SSSR [Devonian and Lower Carboniferous /Tournai/ algae of Central Part of Russian Platform. Fossil algae of the UdSSR]. Nauka, Moskwa (In Russian).

Bassoulet. J.-P., 1979. Essai de classification des Dasycladales en tribue. Bull. Centr. Rech, Explor. 3(2), 429-442.

Berchenko, O.I. 1981. Izvestkovyje vodorosli turneiskikh otlozhenii Donbassa [Tournaisian calcareous algae of Donbass]. Naukova Dumka, Kyiv (In Russian).

Berchenko, O.I., Sukhov, O.A., 2013. Izvestkovyje vodorosli vizeiskikh otlozhenij Dono-Dneprovskogo progiba
P1. 2
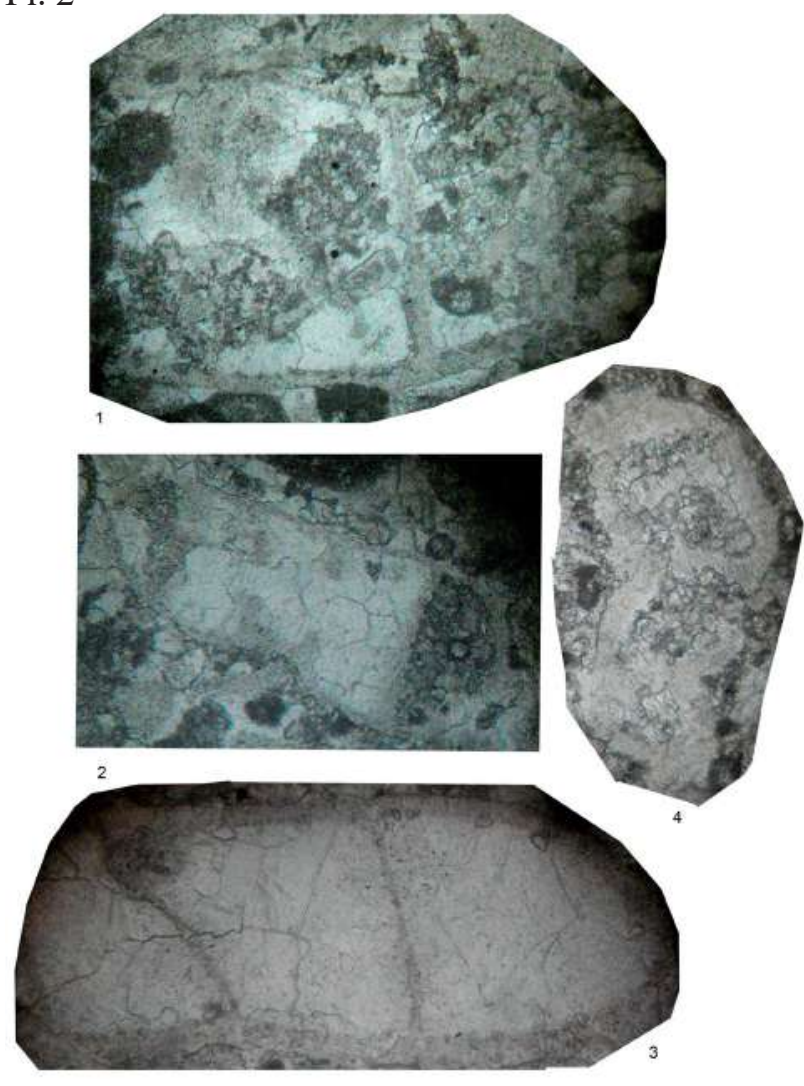

700 MKM

P1. 2 $\mathrm{C}_{1 \mathrm{c},}^{\mathrm{v}}$

Fig. 1 depth 188.4 m, Hlybokinsky horizon, zone

Fig. 2, 4 depth 156. 4-160 m, Hlybokinsky horizon, zone $\mathrm{C}_{1}{ }^{\mathrm{v}}$,

Fig. 3 depth 154.4-156.4 m Hlybokinsky horizon, zone $\mathrm{C}_{1}{ }_{\mathrm{d}}$.

[Visean calcareous algae of Don-Dnipro depression]. Naukova Dumka, Kyiv (In Russian).

Berger, S., Kaever, M.J., 1992. Dasycladales, an illustrated monograph of a fascinating algal order. Stutt.: Georg Tiem Verlag.

Brady, H.B., 1876. A monograph of Carboniferous and Permian Foraminifera (the genus Fusulina excepted). The Paleontolographical Soc. 30.

Chuvashov, B.I., Luchinina, V.A., Shuisky, V.P., 1987. Iskopajemyje izvestkovyje vodorosli [Fossil calcareous algae]. Nauka, Novosibirsk. (In Russian). 
Elliott, G.F., 1970. Calcareous algae new to the British Carboniferous. Paleontology. 13(3), 443-450).

Ivanova, R.M., 2013. Izvestkovyje vodorosli karbona Urala [Carboniferous calcareous algae of the Urals]. Ekaterinburg: Ural Division RAS (In Russian).

Maslov, V.P., 1956. Iskopajemyje izvestkovyje vodorosli SSSR [Fossil calcareous algae of the UdSSR] Trudy Inst. Geol. Nauk AN SSSR 160, 1-301. Moskva. (In Russian).

Mamet, B. et Roux A., 1974. Sur quelques algues tubulaires scalariformes de la Tethys Paleozoïque. Rev. de Micropaleontol 17(3), 134-156.
Skompsky, S, 1987. The dasycladacean nature of Late Paleozoic palaeoberesellid algae. Acta geologica Polonica. 37 (1-2), 21-31.

Skompski, S., 1996. Stratigraphic position and facies significance of the limestone bands in the the subsurface Carboniferous succession of the Lublin Upland. Acta geologica Polonica. 46 (3-4), 171-268.

Termier H. G., Vachard D., 1977. On Moravamminida and Aoujqalida (Porifera, Ischyrospongio) Upper Paleozoic, Pseudo-Algae. Fossil Alqae, 215-219. 